\title{
Sébastien Guex
}

\section{The Origins of the Swiss Banking Secrecy Law and Its Repercussions for Swiss Federal Policy}

\begin{abstract}
For all its notoriety and controversial character, the history of Swiss banking secrecy remains largely unexplored. This article traces the crucial phases of its development. It reveals that the maintenance and reinforcement of banking secrecy represented a major objective of Swiss authorities throughout the twentieth century, and exerted a substantial influence on Swiss domestic and foreign policy. It demonstrates that, contrary to popular opinion, the institution of Swiss banking secrecy did not arise from a desire to protect the funds deposited in Switzerland by Jewish victims of Nazi persecution but rather had substantially different origins. Moreover, this article shows that Swiss banking secrecy gave rise to tensions between Switzerland and the Great Powers, especially during and after World War II, when it poisoned relations between Switzerland and the United States.
\end{abstract}

$\mathrm{T}$ he recent controversy over how Swiss bankers handled the bank accounts of Jewish victims of Nazi persecution has revealed, once again, the degree to which the practice of Swiss banking secrecy remains the subject of widespread, impassioned conflicts and debates. My principal thesis in this article is that, throughout the twentieth century, the maintenance or even reinforcement of banking secrecy represented a major objective of Swiss authorities, one that exerted a substantial influence on Swiss domestic and foreign policy and on Swiss relations with other countries. Moreover, as I will show through an analysis of Switzerland's banking policy before World War II and im-

SÉBASTIEN GUEX is an assistant professor of contemporary history at the University of Lausanne, Switzerland.

In the final editing of this article, I benefited from the critical remarks of Luc Thévenoz, professor at the Faculty of Law of the University of Geneva, to whom I would like to express my gratitude. I would also like to thank Professor Robin Kemball for his help on the translation.

Business History Review 74 (Summer 2000): 237-266. (1) 2000 by The President and Fellows of Harvard College. 
mediately after, the Swiss authorities have shown a consistency in their policies over the years.

Despite the numerous controversies, Swiss banking secrecy has not been the subject of in-depth historical research. In particular, the existing studies do not analyze banking secrecy as a strategy that is consistent with the peculiar conditions of the Swiss financial center and, moreover, one that was devised to favor the conditions for its expansion. True, there exists an abundant literature on the topic, but it comprises legal works, on the one hand, and journalistic studies, on the other. Studies of the first type present a legal analysis of banking secrecy but dedicate no more than one or two pages to either the birth and evolution of the practice or its role in determining federal policy. Nevertheless, a few of these works allot more space to the history of banking secrecy, namely, the studies by Richard Zondervan, Le secret bancaire suisse et sa légende (1973), and Maurice Aubert, Le secret bancaire suisse (1995). As for journalistic works, their focus is on uncovering the story's sensational aspects rather than on presenting a logical historical analysis, and they are not well documented. ${ }^{2}$ However, some of these works supply the reader with useful information. For instance, Nicholas Faith's book, Safety in Numbers (1982), reports on several interesting episodes in the twentieth-century saga of banking secrecy. Another work, by Tom Bower, entitled Blood Money (1997), covers the Swiss banks' role in World War II. In brief, all these analyses are fragmentary, so that, even today, the history of the Swiss Banking Secrecy Law is almost entirely misunderstood.

${ }^{1}$ The principal works in this category are the following: Paul Lavanchy, Das Bankgeheimnis in der schweizerischen Gesetzgebung mit besonderer Berücksichtigung des Stenerrechts (Zürich, 1935); Georges Capitaine, Le secret professionnel du banquier en droit suisse et en droit comparé (Genève, 1936); Adolf Jann, Der Umfang und die Grenzen des Bankgeheimnisses nach schueizerischem Recht (Altdorf, 1938); François Delachaux, Le secret professionnel du banquier en droit suisse (Neuchâtel, 1939); Richard Zondervan, Le secret bancaire stisse et sa légende. Une appréciation critique (Bruxelles, 1973); Le secret bancaire dans la C.E.E. et en Suisse (Paris, 1974); Raymond Farhat, Le secret bancaire. Etude de droit comparé (France, Suisse, Liban) (Paris, 1980); Maurice Aubert et al., Le secret bancaire suisse. Droit privé, pénal, administratif, fiscal, procédure, entraide et conventions internationales (Berm. 1995); Stephan M. Pieper, Rechts- und Amtshilfe in Steterangelegenheiten durch die Schtceiz insbesondere im Hinblick auf das schweizerische Bankgeheimnis (Frankfurt, 1995).

${ }^{2}$ Cf., for example, Theodore Reed Fehrenbach, The Suiss Banks (New York, 1966); Leslie Waller, The Swiss Bank Connection (New York, 1972); Thurston Clarke and John J. Tigue, Jr., Dirty Money: Suiss Banks, the Mafia, Money Laundering, and White Collar Crime (London, 1975); Christoph Büchenbacher, Tatsachen über das schweizerische Bankgeheimnis (Zürich, 1977); Nicholas Faith, Safety in Numbers: The Mysterious World of Suiss Banking (London, 1982); Jean Saunier, Le pouvoir des banques suisses (Paris, 1982); Tom Bower, Blood Money: The Suiss, the Nazis and the Looted Billions (London, 1997); Adam LeBor, Hitler's Secret Bankers: How Suitzerland Profited from Nazi Genocide (London, 1997). 
No work adequately examines the origins of the Secrecy Law. In fact, for many years, one or two particularly persistent legends have circulated concerning this topic. Since the late 1960 s, the most widely disseminated story asserts that the Swiss Banking Secrecy Law was introduced in 1934, with the adoption of the Federal Banking Law, and that it was a measure designed to protect the victims--mainly Jewish-of Nazi persecution. Perhaps the most striking summary of this version, written by Philippe de Weck, former president of the Union Bank of Switzerland, can be found in a reference work, Nouveau manuel de la politique extérieure suisse (New Manual of Swiss Foreign Policy), published in 1992. Having called the reader's attention to "the Nazi persecution of Jewish German citizens which provoked an influx of the victims' capital" to Switzerland, de Weck continues:

... it was because of this influx of capital belonging to the victims of persecution that the famous Banking Secrecy Law was introduced into Swiss legislation. Emissaries of Nazi organizations actually followed the immigrants to Switzerland. They endeavored to obtain information concerning the capital they held in Switzerland. Once in possession of such information, they would have been in a position to blackmail members of their families still in Germany. It was in order to prevent such information from coming into the possession of Nazi emissaries that a particularly stringent Banking Secrecy Law was introduced into Swiss legislation at that time. It was a courageous act at a time when Germany, so close to Switzerland, was so powerful. From this point of view, Switzerland played an international financial role at that moment in history which came close to [being] an humanitarian action towards a category of people whose terrible misfortune is also part of history. ${ }^{3}$

This version is still widely accepted even today, notably in foreign publications. In February 1996, for example, the Economist wrote: "Many Swiss are proud of their Banking Secrecy Law, because it has admirable origins (it was passed in the 1930s to help persecuted Jews protect their savings)."4 A book published in 1997, albeit critical of the attitude of Swiss banks during the Nazi period, affirms the point: "Banking Secrecy ... w was introduced in 1934 -in part to protect Jews who deposited money in Swiss banks."

\footnotetext{
${ }^{3}$ Philippe de Weck, "Le rôle de la Suisse comme place financière internationale," in A. Riklin et al., eds., Nouveau manuel de la politique extérieure suisse (Bem, 1992), 878. This and all subsequent translations in this article are mine, unless indicated otherwise.

${ }^{4}$ The Economist, 17 Feb. 1996, 78.

${ }^{5}$ A. LeBor, Hitler's Secret Bankers, 3.
} 
This version does not correspond with the facts. In the first place, the Swiss Banking Secrecy Law was not introduced in 1934 but was merely reinforced at that time. Second, and more important, in the present state of research it has by no means been established that Swiss ruling circles-by this term, we refer to the government circles and main employers' associations-adopted this measure for humanitarian reasons, namely, with the intention of protecting Jews from Nazi persecution.

A final point: In the last five years, the Swiss Banking Secrecy Law has been even more severely questioned on the international scene because of the way Swiss bankers have handled the accounts of victims of the Nazis since the end of World War II. However, I will not deal here with this aspect of banking secrecy. There are some interesting studies on this topic, notably that of Peter Hug and Marc Perrenoud, In der Schweiz liegende Vermögenswerte von Nazi-Opfern und Entschädigungsabkommen mit Oststaaten (Assets of Nazi Victims in Switzerland and Compensation Agreements with Eastern States). ${ }^{6}$

\section{Swiss Banking Secrecy Law Prior to 1934}

Since the end of the nineteenth century, the practice of secrecy has been deeply rooted in Swiss banking activity. At the time, this practice was based on tradition rather than on a concrete law or set of laws. Several laws existed that could be used as a legal basis for the practice of banking secrecy. However, these were either adopted only in a few cantons (the Swiss federal state is made up of twenty-two cantons that are the equivalent of the U.S. states), where they affected only the public banks, or, in the case of federal laws, bore an extremely unclear relation to banking secrecy. What was clear, however, was that banking secrecy was a matter of civil, not criminal, law. Consequently, its violation resulted in civil, but not penal, proceedings. In other words, sanctions could be imposed only if a claim had been lodged by the injured party, and in the form of damages. This limitation did not prevent banking secrecy from being widely practiced. In particular, Swiss authorities found it difficult to penetrate banking secrecy in pursuit of fiscal objectives.

Thus, although banking secrecy was already established in Swiss banking and political mores at the turn of the century, its importance

\footnotetext{
${ }^{6}$ On this topic, cf. Swiss Federal Archives, Flight Funds, Looted Property and Dormant Assets: Status of Research and its Perspectives (Bern, 1997); Peter Hug and Marc Perrenoud, In der Schweiz liegende Vermögenswerte von Nazi-Opfern und Entschädigungsabkommen mit Oststaaten (Bern, 1997); Independent Committee of Eminent Persons (ICEP), Report on Dormant Accounts of Victims of Nazi Persecution in Suiss Banks (Bem, 1999).
} 
began to grow at that time. Indeed, in several European countries, this period witnessed increased taxation of the wealthy propertied classes. In France, for example, the government greatly increased the inheritance tax in 1901 and, during the following years, it began to prepare for the introduction of an income tax on high revenues.

Lacking comparable industrial and commercial power, Swiss banks could in no way compete with financial centers such as London, Paris, or Berlin. However, members of the Swiss banking circles soon realized that the tax increases occurring in several countries offered them an interesting possibility: that of attracting to Switzerland foreign capital seeking to evade domestic taxation considered to be exorbitant.

In this context, the importance of banking secrecy, as it was hitherto adopted and practiced in Switzerland, took on a new dimension. For those in Swiss business circles, banking secrecy was no longer simply an instrument with primarily internal functions that was designed to protect them from the domestic tax authorities. It now also became an instrument with external functions, a lynchpin in the strategy of attracting foreign capital to Switzerland and hence a major asset in international competition.

This explains why Swiss banking institutions initiated massive propaganda campaigns in neighboring countries, extolling the advantages of Switzerland as a tax haven. For example, in an advertising circular distributed in France in October 1910, a major Swiss bank drew attention to the fact that the situation in Switzerland "enables us to manage with the utmost discretion securities entrusted to our care by customers from abroad." This propaganda campaign reached such a level of intensity, even before World War I, that the Swiss minister of economy, fearful of possible retaliatory measures from foreign governments, felt obliged to ask the bankers to lower the pitch of their message. ${ }^{8}$

World War I represented a turning point in the history of Swiss finance. The world conflict introduced a long period characterized in most European countries by a succession of political, financial, and monetary crises, as well as by a massive increase in taxation. In these conditions, foreign capital--especially French, German, Italian, and Austrian-poured into Swiss banks on a scale hitherto unknown. Depositors were attracted by the protection offered by the solidity of the Swiss franc, by the political stability of the country, by its neutrality, by

\footnotetext{
'Circular quoted in Maurice Brion, L'exode des capitaux français à l'étranger (Paris, 1912), 24.

${ }^{8}$ Cf. H. Lüthy and G. Kreis, eds., Documents diplomatiques suisses, v. 5 (Bern, 1983), 901 .
} 
the mildness of its taxation laws, by the obliging nature of its fiscal authorities, and, last but not least, by the existence of banking secrecy. Thanks to the magnitude of the influx, Swiss banks enjoyed a spectacular takeoff. From that time on, an historian writes, "Switzerland became transformed into an international financial center," a transformation sanctioned in 1930 by the establishment in Basel of the Bank for International Settlements. ${ }^{9}$ It is important to point out that Switzerland became an international financial center after World War I by occupying a specific position: that of "a turntable for international capital," that is, a place for the reception of assets coming from abroad, assets that were in turn lent abroad again, but this time under the Swiss flag. ${ }^{10}$ In other words, the principal Swiss banks established their high-ranking position in the world banking hierarchy mainly by through becoming a refuge of choice for foreign capital.

These characteristics of the Swiss financial center multiplied tenfold the importance of the issue of banking secrecy. From World War I onward, banking secrecy became a major-sometimes even the main-stake in relations between Switzerland and a number of other countries. Indeed, the authorities of several foreign countries did not remain inactive when confronted with the massive exodus of international capital to the Swiss haven. On several occasions, they actively tried to stop it, especially in the years following the first World War. For example, whereas the French and Belgian governments did not appreciate their wealthy citizens' transferring assets to Switzerland and thereby escaping taxation, they were even more incensed by the flight of considerable German capital to the Swiss refuge, fearing that this movement of funds might endanger payment of the reparations imposed on Germany by the Versailles Treaty.

From the end of the war, therefore, France and Belgium embarked on a series of relatively modest measures for prevailing on Swiss authorities and financial institutions to limit the practice of banking secrecy. Their goal was to obtain precise information on the identity of certain capital holders, in the hope of being able to exercise pressure on them-or even to take legal action against them-and thereby indirectly discourage the flight of assets to Switzerland.

Swiss ruling circles doggedly, and successfully, refused to make any concession regarding these requests for access, even though, as the

\footnotetext{
${ }^{9}$ Hugo Bänziger, Die Entwicklung der Bankenaufsicht in der Schueiz seit dem 19. Jahrhundert (Bern, 1986), 57.

${ }^{10}$ René Chopard, "La banque suisse face au défi européen," Annales de la Faculté de droit et de science politique de l'Unitersité de Clermond-Ferrand (1989), 246.
} 
Federal Council stated during one of its sessions, "in several countries . . there will be deep resentment against Switzerland because of this attitude."ll The Swiss government left little doubt about the reasons for this policy of obstruction. Any agreement to identify even a few owners of the foreign assets entrusted to the care of Swiss banking establishments, the government explained at the same session, would force it to "go to the length of suspending banking secrecy and forcing the banks to provide information. . . . The importance of banking activity to the Swiss economy calls for the greatest prudence as far as measures against tax evasion are concerned. This is why the Committee of the Swiss Bankers' Association has likewise decided strictly to reject ... any measure combating this evasion."12

\section{The Origins of the Reinforcement of Banking Secrecy in 1934}

Beginning in the second half of 1931, and during the years immediately following, Switzerland experienced the worst banking crisis in its history. Of the eight major banks of that time, one went bankrupt, another survived only because it received massive help from the federal state, and four had to be substantially reorganized. ${ }^{13}$ In addition, from the summer of 1931 onward, the issue of the elaboration of a federal banking law by the Swiss Confederation became a matter of increasing urgency. Not only the workers' movement, headed by the Socialist Party, but also wide sectors of the farmers, represented by the powerful Swiss Farmers' Union (Union suisse des Paysans), and the middle classes clamored for more control over the financial sector. Their main demands were, on the one hand, for the State to introduce some control over banking activities, especially in order to protect the savings of the lower and middle classes. On the other hand, while fighting for lower interest rates, they asked for tighter control of capital export in order to combat the increase in interest rates resulting from growing amounts of capital being invested abroad.

Even though the government had remained hesitant, not to say

\footnotetext{
${ }^{11}$ Minutes of the Federal Council's meeting of 21 March 1924, Federal Archives, Bern [henceforth FAB], E 1004.1.

${ }^{12}$ Ibid.

${ }^{13}$ Cf. Paul Ehrsam, "Die Bankenkrise der 30er Jahre in der Schweiz," in Commission fédérale des banques, ed., Cinquante ans de surveillance fédérale des banques (Zürich, 1985), 83-118; Patrick Halbeisen, "Bankenkrise und Bankengesetzgebung in den 30er Jahren," in S. Guex et al., eds., Krisen und Stabilisierung. Die Schweiz in der Zuischenkriegszeit (Zürich, 1998), 63-68.
} 
reticent, for a long time, it finally relented under the combined influence of this pressure and the mounting difficulties faced by financial establishments. Also, the severe worldwide banking crisis provoked intensified state regulation of banking activities in many countries. ${ }^{14} \mathrm{In}$ January 1933, the Federal Council decided to formulate a banking law. A first draft, outlined in February 1933, already included-significantly enough--an article on banking secrecy. ${ }^{15}$ This bill underwent numerous changes during the phases of preparliamentary and parliamentary debates following its introduction, but it finally passed into law. On the other hand, it is important to note that, during this entire period, the article dealing with banking secrecy occasioned no debate, nor was it modified to any notable degree. In other words, the future article 47 of the Banking Law voted by the Swiss Parliament in November 1934 remained practically identical, in substance if not in form, to the corresponding article of the February 1933 draft.

Article 47 of the Banking Law made the violation of banking secrecy subject to criminal law and the possibility of both heavy fines and up to six months' imprisonment. In principle, such violation had to be automatically prosecuted by the legal authorities, even if the injured party did not sue. The adoption of the 1934 law thus represented a considerable reinforcement of banking secrecy and was the first time that this practice obtained a clear basis in federal law. It was no longer subject to civil law alone, but to criminal law. By recognizing that the safeguarding of banking secrecy was in the public interest, the state in a certain sense conferred on this secrecy law the status of public weal. With its adoption in 1934, Switzerland became, among economically developed countries, the one with by far the most rigorously protected banking secrecy law.

\section{Introduction of the Concept of Supervision of the Banks}

The introduction of an article on banking secrecy in the 1934 law was a response primarily to fears arising in certain banking circlesand more generally in business as a whole-that this law threatened to establish a form of supervision of Swiss banks. Bankers feared that the agents of this supervision, who would have access to the books and reg-

\footnotetext{
${ }^{14}$ Cf. Karl Erich Bom, Geld und Banken im 19. und 20. Jahrhundert (Stuttgart, 1977), $480-537$.

${ }^{15} \mathrm{Cf}$ the two drafts entitled Bundesgesetz iber die Bentfsichtigung der Banken und Sparkassen, by Eduard Kellenberger, 17 and 24 Feb. 1933, FAB E $4110(\mathrm{~A}) / 19 / 40$ and E 6520(A)/1/3; also H. Bänziger, Die Entwicklung, 89-105.
} 
isters of the banks, would leak information about their clients to Swiss-or worse, to foreign-authorities. Such a risk seemed to them even more acute if future investigations were to be directly carried out by federal civil servants, inasmuch as insulation between the various federal departments did not seem sufficiently watertight. Explaining the attitude of banking circles at the time, a major banker later wrote that they could not possibly accept "state inspection" if "they wished to avoid the endangering of banking secrecy that this would imply." 16

It is helpful to recall that this episode in the 1930s had a precedent. At the beginning of 1914, in reaction to difficulties encountered by several important financial establishments, the Swiss government had begun to consider introducing a form of supervision of the banks and had taken steps in this direction. Fearful that such oversight might weaken the practice of banking secrecy, bankers, led by the National Bank and the Swiss Bankers' Association, had expressed misgivings, if not outright rejection. This opposition, followed by the outbreak of World War I and the consequent improvement of the banks' situation, caused the matter to be quickly dropped. ${ }^{17}$

At the time that the question of bank supervision was reintroduced in the summer of 1931, the opposition of businessmen had in no way diminished. Accordingly, they made their agreement to such control dependent on two absolute conditions: First, such regulation should take the mildest form possible and should, under no circumstances, be directly exercised by the State. Second, it must be accompanied by arrangements designed to maintain banking secrecy.

As early as August 1931, Neue Zürcher Zeitung, the highly influential journal of Swiss business circles, published an editorial violently attacking the idea that supervision of the banks might be entrusted to the Confederation. The editorial stressed the fact that regulation of the banks must exclude any "possibility of having access to the financial situation" of the banks' customers, which, it warned, would provoke the withdrawal of Swiss and foreign depositors. ${ }^{18}$ One week later, the Zurich daily repeated its warning at greater length. ${ }^{19}$

In January 1932, the managing director of Crédit Suisse, Adolf Jöhr- a man who played a central role in the elaboration of the 1934

\footnotetext{
${ }^{16}$ Letter from the managing director of Crédit Suisse to the head of the Federal Department of Finance, 9 Feb. 1935, FAB, E 6520(A)/1/1.

${ }^{17} \mathrm{Cf}$. H. Bänziger, Die Entwicklung, 38 49; and Sébastien Guex, La politique monétaire et financière de la Confédération suisse 1900-1920 (Lausanne, 1993), 217-219.

${ }^{18}$ Neue Zïrcher Zeitung, 28 Aug. 1931.

${ }^{19}$ Cf. Neue Zïrcher Zeitung, 3 and 4 Sept. 1931.
} 


\section{Sébastien Guex / 246}

Banking Law-tried to clarify the situation. Writing as a consultant to the head of the federal Department of Finance, Jean-Marie Musy, Jöhr argued that it was extremely important that "the strictest possible secrecy be preserved" and therefore he emphasized that the introduction of such supervision must be accompanied by the adoption of legal measures punishing the violation of banking secrecy: "A matter which regularly provokes reservations [in business circles] is the preservation of absolute discretion during inspections conducted by authorities external to the bank. ... It is therefore essential to establish liabilities in the law itself. It would be extremely desirable if indiscretions could be punished at [the] penal level. ..."20

In February 1932, a director of the Banque d'Escompte Suisse, another of the eight leading Swiss banks, sent a series of propositions concerning bank supervision to the head of the Department of Finance. Among these, several were devised for "preserving strict discretion ... towards all political authorities ..., especially towards fiscal organs and offices ...," and they envisaged severe sanctions in case of violation of this discretionary duty. ${ }^{21}$ Finally, in October 1932, a paper reflecting the preoccupations of the Association of Cantonal Banks was sent to the Department of Finance, likewise insisting on the need, in the event of bank supervision being introduced, to "exercise extreme care to maintain banking secrecy." 22

Alerted by the precedent of 1914 , the federal authorities this time met the expectations of business circles immediately and without ambiguity. From the start, the latter received solid assurances, including the guarantee that bank oversight would not be conducted directly by the State and that such supervision, far from weakening banking secrecy, would actually strengthen it. In September 1931, the federal councilor, J.-M. Musy, gave a speech on "the issue of bank supervision" before the annual assembly of Swiss bankers, in which he declared: "Governmental bank supervision is desirable neither for the State, nor for the bank. .. The intervention of official investigators would alarm . . . customers, who attach great importance to the preservation of discretion, on which they want to be able to rely. The Hight of capital deposited in our banks that might result from the institution of official supervision

\footnotetext{
${ }^{20}$ Vorschläge zur Revision des Obligationenrechts hinsichtlich der Banken-Kontrolle, by Adolf Jöhr, 24 Jan. 1932, FAB E 6520(A)/1/2.

${ }^{21}$ Draft B, Bundesgesetz über die schweizerische Bank- und Börsen-Zentrale, by Fritz Zimmermann-Locher, 3 Feb. 1932, FAB, E 6520(A)/1/2.

${ }^{22}$ Verband Schweiz, Kantonalbanken, Auszug aus den Vorträgen des Herm Jakob Kaderli, 27 Oct. 1932, FAB E 6520(A)/1/2.
} 
would cause our national economy great damage, from which the entire population would suffer." ${ }^{\text {"23 }}$

A few days later, the head of the Department of Finance repeated these guarantees before the Swiss Parliament. "One must be very careful in the field" of bank supervision and not endanger the practice of "banking secrecy," he declared, because "we must try and prevent Swiss or foreign capital, which now works at a profit for our national economy, from being induced to leave our country." ${ }^{24}$ In the same month of September 1931, the president of the Confederation struck a reassuring note. In an important public speech dealing with the "issue of bank supervision," Heinrich Häberlin declared that "the open or covert lifting of banking secrecy would be fatal" because it would only provoke the flight of Swiss and foreign capital. ${ }^{25}$ The federal authorities repeated similar assurances on several occasions throughout $1932 .{ }^{26}$

With such unity among bankers, it is easy to understand why an article enforcing banking secrecy was included in the first draft of the Banking Law. It also clarifies why it not only provoked no criticism but also led to no real debate during the preparliamentary and parliamentary phases. From the point of view of business circles, it represented the indispensable complement to the introduction of bank supervision. Any contention of such an article would have multiplied tenfold the risk of a veto from these circles and their representatives and so have endangered the entire law. For this was specifically an outcome that the Socialists, who favored the fastest possible implementation of the supervision of banking activities, desired to avoid. This situation partly explains the paradoxical absence of any reaction from those political circles that were the main opponents of banking secrecy. ${ }^{27}$

\section{Strong-Arm Tactics by France against the Flight of Capital to Switzerland}

A second cause for the reinforcement of banking secrecy was the danger of external threats. Ever since 1930, the world economic crisis had confronted many of Switzerland's neighboring states with grave 195.

${ }^{23}$ Speech reported in Bulletin de la Société de Banque Stiisse, no 6, late Oct. 1931.

${ }^{24}$ Bulletin sténographique officiel de l'Assemblée fétérale-Conseil national, Bern, 25 Sept. 1931, 663.

${ }^{25}$ Speech reported by the Neue Zürcher Zeitung, 18 Sept. 1931.

${ }^{25} \mathrm{Cf}$. especially the Bulletin sténographique officiel de l'Assemblée fédérale-Conseil national, Bern, 8 June 1932, 252.

2. On this last aspect, cf. ibid., 27 Sept. 1932, 705 . 


\section{Sébastien Guex / 248}

financial and monetary difficulties, sharpening internal political tensions. As at the end of World War I, these states-mainly France and Germany-were confronted with new and massive flights of capital toward countries of refuge, most often to Switzerland. They again initiated a series of measures designed to hinder this outflow.

Consequently, the Swiss federal authorities and the Swiss financial market once more found themselves involved in a predicament similar to the one that arose immediately after World War I. This time, however, the threat was perceived by other countries to be appreciably more serious. Compared with the measures imposed previously, and probably precisely because of their inefficacy, those adopted at the beginning of the 1930s were noticeably more drastic.

Thus in Germany, from July 1931 onward, Chancellor Heinrich Brüning's government enacted a number of increasingly rigorous decrees designed to interrupt the flight of German capital abroad and, if possible, even to induce the repatriation of funds already deposited in foreign countries. One decree, for example, required that all assets in foreign currency owned by German citizens be declared to the Reichsbank and, if requested by the latter, sold in exchange for Reichsmarks, ${ }^{25}$ In addition to these measures, the German authorities made various attempts to conduct banking espionage in Switzerland during the following years in order to obtain information from employees of Swiss banks about their German customers. ${ }^{29}$

From the Swiss point of view, however, by far the most disturbing steps were taken not by Germany but, as occurred after World War I, by France, where a new center-left government, presided over by the radical Edouard Herriot, had been appointed in June 1932. Faced with grave budgetary difficulties, and in an effort to strengthen its wavering popularity, this new government announced a range of measures directed against the flight of capital and tax evasion. In this context, a spectacular blow was delivered against Switzerland ${ }^{30}$

On October 27, 1932, the Paris offices of one of the eight leading Swiss banks of the period, Basler Handelsbank, were searched by the French authorities and numerous documents were seized. The latter revealed that Basler Handelsbank had been organizing transfers of capital and tax evasion for the benefit of rich French clients for a long

${ }^{28} \mathrm{Cf}$. esp. Notverordnung gegen die Kapital- und Steuerflucht, 18 July 1931, Reichsgesetzblatt 1931, v. 1,373ff.

${ }^{29} \mathrm{Cf}$. Beat Balzli, Les administrateurs du Reich. La Suisse et la disparition des biens des victimes du nazisme (Genève, 1997), 109-110; and H. Bänziger, Die Entuicklung, 115-116.

${ }^{30} \mathrm{Cf}$. N. Faith, Safety in Numbers, $64-72,81$. 
time, in contravention of French law. During the succeeding days, further search operations were carried out, implicating another leading Swiss bank, the Banque d'Escompte Suisse, as well as a private bank in Geneva.

The affair created an enormous sensation. Swiss and French newspapers devoted long columns to the subject for several weeks, and, on November 10, 1932, a stormy debate erupted in the French Parliament. Other countries were also affected by the scandal: in the same month, for example, a leading German newspaper published a long article under the headline "French Attack on Swiss Banking Secrecy."31

Such reactions were hardly surprising. On the one hand, it soon emerged that the amounts eluding French taxation were extremely large. The figure most frequently mentioned at the time was 1 billion French francs, or some 200 million Swiss francs. In fact, the amount was probably at least twice as high (the equivalent of roughly 40 to 50 billion of today's French francs). ${ }^{32}$ In addition, the documents confiscated during the requisitions enabled the authorities to establish a list of persons involved that ran to over a thousand names. Some of these names were published. Among them were numerous prominent French figures: three senators, a dozen generals, two bishops, former ministers, leading industrialists like the Peugeot family and the Coty family, owners of the influential daily Le Figaro. ${ }^{33}$

The seizures-constituting strong-arm tactics that were most unusual in this type of affair-were alone enough to worry the Swiss authorities and business circles. The French authorities, however, did not content themselves with firing this warning shot. Legal proceedings were immediately started against the three Swiss banks, and their assets in France-approximately 80 million French francs for the Basler Handelsbank alone-were frozen. On November 10, 1932, after a long and turbulent debate, the French Chamber of Deputies adopted a resolution requiring the government to take “. . . all effective measures to prevent and repress fiscal fraud that has all too long been tolerated." ${ }^{4}$ During the debate, the minister of finance adopted an even more menacing stance, defining the government's aim as that of ". . obtaining the suppression of fiscal fraud, either by means of already existing texts

${ }^{31}$ Kölnische Zeitung, 22 Nov. 1932; cf. also the Viennese Neue Freie Presse, 23 Nov. 1932; and the Czech newspaper Bohemia, 14 Dee. 1932.

${ }^{32} \mathrm{Cf}$. Eduard Kellenberger, Kapitalexport and Zahlungsbilanz, v. 2 (Bern, 1942), 81; and Le Petit Parisien 4 April 1935.

${ }^{33}$ Joumal officiel, 11 Nov. 1932, 2998-2999, and Le Matin, 24 Nov. 1932.

34 Jotmal officiel, 11 Nov. 1932, 3004. 
or by new ones that will soon be submitted to you ..., but also, gentlemen, in certain cases in which a text seems impossible to formulate and is above all ineffective, repression by all the means available to a Government." 35

Barely one week after this discussion, on November 16, 1932, two members of the board of administration of the Basler Handelsbank were summoned by the French authorities, who requested them to authorize French officials to examine the bank's books on the Basel premises. The Swiss administrators' refusal led to the immediate imprisonment of one manager and one assistant manager of the Basel establishment, who had both been present at the October 27th requisition in Paris. Both were released only after spending two months in custody. This measure was designed to increase pressure on the Basel bank in order to force it to lift banking secrecy and allow free access to its registers. ${ }^{36}$

On November 21, 1932, the French authorities presented a new initiative, asking the Federal Council for judicial cooperation. ${ }^{37}$ In tandem with this move, French authorities were resorting to the sort of measures alluded to by the French minister of finance in his appearance before the Chamber of Deputies. In a report, sent to the president of the Confederation from Paris in December 1932, the Swiss minister drew the attention of his superior to information that had reached him about banking espionage practiced by "secret agents of the French Government ... in several Swiss towns" concerning "various French clients of our banks," asking him to examine "the possibility of taking measures to prevent these activities." ${ }^{38}$

From January 1933 onward, the situation began to quiet down, mainly because the French government led by Herriot had been forced to resign in mid-December of 1932. Nevertheless, the measures directed against the Swiss banks, particularly against the Basler Handelsbank, were not finally settled until some twelve years later.

At the same time, the Swiss financial center and the Swiss Banking Secrecy Law were defended with the utmost determination; the federal authorities refused to examine any claims, whatever they might be,

${ }^{35}$ Ibid., 3002.

${ }^{36}$ Cf. letter from the Basler Handelsbank to the Federal Political Department, 4 Jan. 1933, and its annexes, as well as the Memorandum of the Basler Handelsbank for the Federal Political Department, 27 Oct. 1936, FAB E 2001(D)/1/64.

${ }^{37} \mathrm{Cf}$. letter from the Police Division of the Federal Department of Justice and Police to the Federal Political Department, 14 Dec. 1932, FAB E 2001(D)/l/64.

${ }^{38}$ Letter from the Swiss ambassador in France to the president of the Confederation, 22 Dec. 1932, FAB E $2001 / \mathrm{D} / 1 / 64$. 
emanating from France. They thus categorically rejected the French request for judicial cooperation.

An internal document explained this attitude, emphasizing that "from the Swiss point of view, it would in no way be in our interest to grant French agents judicial cooperation which might have very unfavorable repercussions on the substantial business accruing to our banks from foreign deposits." 39 Meanwhile, Swiss business circles and their various representatives vigorously denounced the French measures as a campaign aimed at weakening, even ruining, the Swiss financial center. At the end of November 1932, for instance, the Journal de Genève, which was close to Geneva banking circles, published an editorial entitled "The Offensive against Switzerland," which stated: "There is an obvious attempt to sow anxiety, in particular to frighten French citizens who have deposited their capital in Switzerland. .. . It is not just a matter of acceptable action against tax evasion . . but a campaign against Swiss finance as a whole." At the same time, the Finanz-Revue spoke of "a fight by the French left-wing bloc directed against Swiss banking secrecy." ${ }^{41}$ In December 1932 and January 1933, the Neue Zürcher Zeitung published a series of commentaries implying that a "veritable hate campaign" was being waged against Swiss banks. ${ }^{42}$

In this context, financial circles repeatedly called for reinforcement of the banking secrecy. On November 23, 1932, the Finanz-Revue expressed the hope that ". . . the campaign led by the French left-wing bloc against Swiss banks" might lead to a state of "increased confidence in Swiss banking secrecy."43 However, the most significant factor in this connection was a long article published by the Neue Zürcher Zeitung on January 10,1933. This article was written by one of the managers of the Banque d'Escompte Suisse- the same man who, a year earlier, had sent the head of the Department of Finance a draft of the banking law that already included a clause reinforcing banking secrecy. The author emphasized the fact that banking secrecy ". . . constitutes an excellent asset for the banks and the economy" of Switzerland and stated that "one cannot conceive that Switzerland could maintain the strength of its banks, which is in the interest of its economy as a whole . . thanks to the confidence that they inspire internationally, without the mainte-

\footnotetext{
${ }^{39}$ Letter from the Federal Political Department to the Swiss Embassy in Germany, 17 Nov. 1932; cf. also letter from the Federal Political Department to the Swiss Legation in France, 12 Nov. 1932, FAB E 2001 (D)/1/64.

${ }^{40}$ Journal de Genève, 26 Nov. 1932.

41 Finanz-Revue, 23 Nov. 1932; see also 16 Nov. 1932.

${ }^{42}$ Neue Zürcher Zeitung, 23 Dec. 1932; see also 4 and 21 Dec. 1932 and 10 Jan. I.933.

${ }^{4}$ Finanz-Revue, 23 Nov. 1932.
} 


\section{Sébastien Guex / 252}

nance of strict respect for and explicit legal protection of banking secrecy [einen positiven Schutz]."44 He went on to stress that up to now this secrecy had been based exclusively on civil law. Referring implicitly to the measures being enacted by France, the author concluded by expressing the hope that the federal state take upon itself directly the task of protecting banking secrecy by giving the latter a basis in public law:

Inasmuch as . . it is not only the banks but also the Swiss economy in general that have a fundamental interest in maintaining banking secrecy, this implies in a certain sense that the State should assume legal responsibility for seeing this secrecy respected. Recently our attention has several times been drawn to this aspect in connection with various attempts at banking espionage in Switzerland. Such attempts, ably and categorically opposed by Swiss banks, clearly represent a menace to the economy and hence, ultimately, to the financial and economic independence of the country.

It is worth recalling here that the first draft of the banking law elaborated by the federal authorities dates from February 1933. It is hardly surprising, therefore, with French threats just beginning to diminish, that the draft should have included a clause written to consolidate banking secrecy. For Swiss ruling circles, this was a matter of sending out a clear message to foreign customers who felt insecure after the procedures started by the French authorities, namely, that Swiss banking secrecy would continue to be defended even more rigorously in the future.

The Swiss also viewed it as a matter of safeguarding against a danger that the French affair had highlighted: that of seeing any bank, under strong pressure from a powerful foreign government, itself take the initiative in providing access to its books and thereby risk provoking a wider crisis in confidence that would affect the foreign clientele of Swiss banks generally. It would seem that the Basler Handelsbank nearly succumbed to this temptation following the freezing of its assets in France and the imprisonment in Paris of its two managers. ${ }^{45}$ By making the violation of banking secrecy an offense that would be automatically prosecuted, in principle, by the Swiss authorities, the 1934 law diminished this danger.

\footnotetext{
${ }^{44}$ Neue Zürcher Zeitung, 10 Jan. 1933.

${ }^{45} \mathrm{Cf}$. letter from the Swiss ambassador in France to the Federal Political Department, 17 Nov. 1932, FAB E 2001 (D)/1/64.
} 


\section{Change of Attitude by the Federal Court Regarding Sequestration and the Socialist Threat}

Several other factors intervened in the reinforcement of banking secrecy. In 1930, the Federal Court, the supreme Swiss legal authority, modified its policy regarding sequestration. In order to facilitate proceedings in cases of bankruptcy, the Court decided to widen the banks' obligation to lift banking secrecy and provide information about their customers if a writ of sequestration were delivered to them. This decision raised grave discontent in banking circles. First the Basler Handelsbank, followed by the Crédit Suisse, appealed to the Federal Court against this new conception in an attempt to force a reversal of the decision. In March 1932, the appeal of the Basler Handelsbank was rejected. Several leading German newspapers jubilantly reported this rejection under the headline "Banking Secrecy Partially Lifted in Switzerland." The ruling provoked the first of several acrimonious articles against the federal judges in the Neue Zürcher Zeitung. ${ }^{46}$

In September 1932, the appeal by the Crédit Suisse was likewise rejected. This was too much and, in December 1932, the Neue Zürcher Zeitung published another long article sharply critical of the Federal Court. It stressed that the "economic damage resulting from such an attitude is evident. The new conception of the Federal Court has several times been used abroad ... to campaign against Swiss banks, and certain tabloids have declared that banking secrecy has been partially lifted in Switzerland." 47

Banking circles, however, were not preoccupied by this aspect alone. They were even more concerned that the federal judges' new conception would facilitate what they called "foreign banking espionage," or attempts by foreign fiscal authorities to obtain information on capital that had found its way to Switzerland. It would seem that the tax-evasion and fiscal-fraud affair uncovered in France in late October of 1932 had nourished this fear. The French authorities did, in fact, try to obtain information on capital deposits in Switzerland by means of the writ of sequestration. Thus, in the case of François Coty and his family, the French authorities managed to arrange for writs of sequestration to be delivered to no less than thirty-one Swiss banks. ${ }^{48}$

Whatever the true extent of the danger, Swiss banking circles were

\footnotetext{
${ }^{46}$ Reported in Neue Zürcher Zeitung, 9 April 1932; see also 8 March 1932.

${ }^{47}$ Neue Zïrcher Zeitung, 21 Dec. 1932.

${ }^{48} \mathrm{Cf}$. Otto Huber, Die Geheimhaltungspflicht des Beauftragten unter spezieller Berïcksichtigung des Bankgeheimnisses (Bern, 1936), 115.
} 
not prepared to risk it. Thus, the article in the Neue Zürcher Zeitung quoted above strongly emphasized the fact that "the change in the Federal Court's conception must be rejected all the more" inasmuch as it encourages "foreign banking espionage in Switzerland"; hence "the banks expect the Federal Court to revert to its previous interpretation. ..." In March 1933, the same newspaper discussed the matter at great length once again. It declared that "Swiss banks have built themselves an international reputation thanks to the confidence they inspire abroad, and thanks to this confidence they administer extensive foreign capital. This confidence is based inter alia on the fact that the State to a large extent refrains from interfering with banking secrecy. . . ."49 The article adds that, if the Federal Court were to maintain its new conception, it ". . would leave the door wide open to banking espionage. ... A foreign fiscal authority could then, directly or indirectly, easily obtain information on its citizens' banking assets in Switzerland." The result would be "the disruption" of the confidence placed in Swiss banks.

In these conditions, the reinforcement of banking secrecy contained in the 1934 law could only lend further support and legitimacy to the bankers' opposition to the Federal Court. The aftermath serves as a good illustration of this point. True, the federal judges never formally went back on their 1930 decision. The banks, however, taking their stand on the 1934 law, refused to acknowledge it, thereby defying the supreme legal authority of the country; and the latter, in the words of a specialist writing some forty years later, ". . . would seem to have resigned itself to the inevitable. 50

Banking secrecy was further reinforced by another factor. The Swiss workers' movement and its principal constituent, the Socialist Party, were very hostile to banking secrecy because this practice made any attempt by fiscal authorities to counter fiscal fraud very difficult. Therefore, they had for years been trying to obtain the relaxation-and even the suppression - of this practice, particularly at the end of World War I, on the occasion of the parliamentary debates related to the reform of the fiscal system of the Confederation. During these debates,

\footnotetext{
${ }^{49}$ Neue Zïrcher Zeitung, 7 May 1933. It should also be noted that, in December 1933, the law professor Robert Haab, son of the former federal councilor of the same name (member of the Swiss government from 1917 to 1929), also insisted, in a reference to the demande de sequestre presented by the French authorities in the case of François Coty, on the "regrettable fact" that the new conception of the Federal Court considerably increased the possibilities of "spying on the financial situation of specific persons"; Robert Haab, "Die rechtliche Stellung des dritten Gewahrsaminhabers im Arrestverfahren," Zeitschrift des Bernischen Juristenvereins, v. 69 (Dec. 1933), 558-559.

${ }^{50}$ Maurice Aubert et al., Le secret bancaire suisse (Bern, 1976), 128.
} 
the Socialists had fought vigorously for the introduction of a temporary federal tax on income and property and, in this context, the lifting of banking secrecy. The Socialist offensive against banking secrecy at the time enjoyed a certain amount of support from the Swiss Farmers' Union. In the Swiss Parliament, the Socialist representatives formed only a small minority: 49 of 233 . Nevertheless, their motion was only defeated by a narrow margin. This can be explained by the fact that the motion found support from a large number of agricultural representatives who were members of the conservative parties. ${ }^{51}$

From the beginning of the 1930 s on, renewed discussion of federal fiscal policy was prompted by the Confederation's budgetary difficulties arising from the economic crisis. The question of a direct federal income tax was once more seriously discussed, and with it the specter of banking secrecy being lifted loomed once again. In 1932, the Socialist Party launched an initiative calling for a federal tax on income and property, which collected a considerable number of signatures..$^{52}$ In October 1933, during parliamentary debates on a financial reform project proposed by the federal authorities as an alternative to this initiative, Socialist deputies renewed their charge, calling for a clause in this reform that would lift banking secrecy in order to counter fiscal fraud in Switzerland. True, their demand was once again rejected, but their spokesman issued a serious warning. "Rest assured," he declared to the right-wing majority of the National Council, "that this is certainly not the last time that we shall propose it. ..."53

It was also as a protection against such dangers, mounted, in a certain sense, by the "enemy within," that an additional bulwark was erected around banking secrecy. Business circles were concerned with what was happening not only at the national but also at the cantonal level. In the early 1930 s, the workers' movement obtained electoral gains in several cantons. This upsurge presaged the assumption of power by Socialist majorities, as in fact occurred in the canton of Geneva in the autumn of 1933. It was feared that such majorities might enact fiscal reforms at a cantonal level, accompanied by measures directed against banking secrecy. ${ }^{54}$ With the adoption of the 1934 Banking Law, however, this danger was greatly di-

${ }^{51}$ Cf. S. Guex, La politique, $412-416$.

${ }^{52}$ Cf. Oswald Sigg, Die eidgenössischen Volksinitiatiten 1892-1939 (Einsiedeln, 1978), $164-173$.

${ }^{53}$ Bulletin sténographique officiel de l'Assemblée fédérale-Conseil national, Bern, 4 Oot. 1933,526 .

${ }^{54} \mathrm{Cf}$, for example, Journal de Genève, 13 Oct. and 5 Dec. 1933. 
minished, as any such cantonal measures would henceforth be in contradiction with a federal statute that, in principle, would take precedence.

One important point concerning the representatives of the workers' movement remains to be clarified. As I reported earlier, they were hostile to the idea of banking secrecy. During the preparliamentary and parliamentary phases of discussion on the Banking Law, however, they kept silent and did not oppose article 47 , despite its reinforcement of the principle of banking secrecy. How is this attitude to be explained? Could it be partly interpreted along the lines of Hugo Bänziger's surmise that "left-wing political parties" were anxious to "protect the wealth of politically persecuted persons"? " Very few convincing arguments support such an hypothesis, even though one Socialist national councilor's ambiguous declaration in July 1932 could be construed in this sense.$^{56}$ In fact, a more probable explanation of this lack of reaction can be found in the following three combined factors: First, as we have seen, Socialist deputies had suffered a crushing defeat in their attempt to obtain the lifting of banking secrecy in October 1933; that is to say, only a few weeks before the beginning of the parliamentary procedure examining the draft of the Banking Law. Their chances of changing the course of events so soon after this failure were clearly negligible. Second, as we have also seen, to question article 47 of this law was to increase the risk of seeing the whole project crumble. Now the Socialists were eager to see some supervision of the banks introduced as quickly as possible. Finally, the draft version of the Banking Law raised a whole series of questions, in addition to the supervision of the banks, which had been at the center of the claims of the workers' movement for years. These issues, having to do with control of the exportation of capital and monitoring the interest rate in Switzerland, therefore monopolized the attention of their representatives at this stage.

\section{Renewed Confrontation over Swiss Banking Secrecy Law at the End of World War II}

In the course of the twentieth century, the most serious challenge to the Swiss Banking Secrecy Law took place at the end of World War II. During the war, Switzerland maintained a neutral position on a dip-

${ }^{55}$ H. Bänziger, Die Entwicklung, 117.

${ }^{56} \mathrm{Cf}$. Bulletin sténographique officiel de l'Assemblée fédérale-Conseil national, Bern, 5 July 1932,405 . 
lomatic level, a claim that cannot be made for its politics in the economic sphere. In fact, from June 1940 on, following the collapse of France, Swiss ruling circles virtually integrated the Swiss economic and financial apparatus within the economic sphere of the Axis powers. Germany and Italy benefited from a certain number of favors essential to their war effort: delivery of strategic equipment, transit through the Alpine tunnels, supply of electricity, and, finally, financial support. Indeed, in the financial arena, Switzerland found itself ardently solicited during World War II. From the summer of 1940 on, the Swiss franc presented two major advantages: on the one hand, it remained a very strong currency, and, on the other, it was the only European currency that was almost freely convertible during the entire course of the war. That is why the Swiss banks were in a position to participate in a large number of international financial transactions of all kinds. For instance, they purchased considerable amounts-worth 1.2 billion Swiss francs-of Nazi gold, and they financed-in anticipation of receiving appreciable benefits-substantial credits to the Axis powers: 1.1 billion Swiss francs to Nazi Germany and 400 million Swiss francs to Mussolini's Italy.

The Swiss financial center could therefore maintain its strong position despite the war. What is more, at the end of the war, it saw the promise of excellent, not to say grandiose, prospects, thanks to different assets: the preservation of the strength of the Swiss franc; the maintenance of the essential infrastructure and international networks of the banks, financial societies, and insurance companies; very free capital and currency circulation; and, finally, a lenient taxation system compared with international norms. The Swiss Bankers' Association was perfectly aware of this promising situation; shortly after the end of the war, it wrote in a report to the federal authorities: “. . thanks to its intact economy and the strength of its credit system, our country is one of the few countries in Europe capable of playing an important role as an international financial center." ${ }^{77}$ These assets would assure the Swiss financial center that considerable amounts of foreign capital would seek refuge in Switzerland and that its role as a "turntable" for international capital would be reinforced. However, this capability required one condition: the upholding of the Banking Secrecy Law, which is exactly where a major problem emerged.

Their intense collaboration with Germany and Italy during the war

\footnotetext{
${ }^{57}$ Report of the Swiss Bankers' Association to the Federal Administration of Finance, 27 March 1946, FAB E $6100($ A) $/ 24 / 2$.
} 
placed members of Swiss economic and political circles in a very delicate situation vis-à-vis the Allied powers at the end of the world conflict. They found themselves isolated on the international scene. Adding to their difficulty, the Allies, in particular the United States, had formidable means of pressure at their disposal. They were in a position to hinder Switzerland's economic exchanges considerably, thanks notably to the blacklists they had drawn up during the war, which included a considerable number of Swiss firms. Since 1941, moreover, the American government had frozen the extensive assets held under the Swiss flag in the United States. It had frozen not only the assets in the possession of the Swiss National Bank and Swiss industrial or banking societies, but also the very sizable capital administered by Swiss banks and financial companies and deposited in the United States before or at the beginning of the war. The amount came to a total of at least six to seven billion Swiss francs (a sum equivalent to almost half the Swiss gross domestic product of that time), some five billion of which were private funds administered by Swiss banks and financial companies.

Members of the leading Swiss economic and political circles thus considered it imperative to make certain concessions to the Allies in order to ensure Switzerland's integration into the new world order. In particular, it became crucial to achieve the suppression of the blacklists and the unfreezing of Swiss assets in the United States. ${ }^{58}$ In this respect, besides the payment of a type of "fine," finally fixed at 250 million Swiss francs by the Washington Agreement, the Allies made two main demands of the Swiss authorities: First, a detailed inventory of all German assets, either in Switzerland or controlled by Swiss firms elsewhere, and their expropriation, in order to guard against the danger of the reconstitution of the Nazi war potential. Second, the precise identification of all private assets emanating from Switzerland and frozen in the United States. In both cases, the Allies demanded a very thorough investigative procedure, to be closely supervised by their own officials, which would enable them to establish not only the exact amount and the national origin of such assets but also the names of their effective owners. ${ }^{59}$

\footnotetext{
${ }^{58}$ On this problem, ef. esp. Marc Perrenoud, "Banques et diplomatie suisses à la fin de la deuxième guerre mondiale," Etudes et sources, nos. 13-14, 1987-1988, 3-128; and Hans Ulrich Jost, "Switzerland's Atlantic Perspective," in M. Milivojevic and P. Maurer, eds., Suiss Neutrality and Security. Armed Forces, National Defence and Foreign Policy (New York, 1990), 110-121.

${ }^{59} \mathrm{On}$ all these questions and those that follow, cf. Marco Durrer, Die schweizerischamerikanischen Finanzbeziehungen im Zweiten Weltkrieg (Bern, 1984); Catherine Schiemann, Neutralität in Krieg und Frieden. Die Aussenpolitik der Vereinigten Staaten gegenüber der Schweiz 1941-1949. Eine diplomatiegeschichtliche Untersuchung (Zürich, 1991), 123262; Linus von Castelmur, Schweizerisch-alliierte Finanzbeziehungen im Übergang vom Zweiten Weltkrieg zum kalten Krieg (Zürich, 1992).
} 
Such claims amounted to demanding the virtual lifting of the Swiss Banking Secrecy Law in favor of the Allies. In other words, the most serious threat to banking secrecy occurred at the moment when, as noted above, the Swiss financial center saw a future filled with excellent prospects. Banking secrecy thus became a central issue in Swiss national and international policy at the end of the war.

One factor reveals the importance attached to this question by Swiss ruling circles. As soon as the power struggle on the battlefield shifted in favor of the Allies, they perceived with considerable insight the implicit dangers in this shift for Swiss banking secrecy and started to plan accordingly. Thus, as early as the beginning of June 1943, even before the Allies had landed in Italy, the problem of the future unfreezing of assets in the United States was mentioned at a conference between the Swiss Bankers' Association and some senior Swiss federal officials. On this occasion, the Swiss ambassador to the United States declared that "after the war ... the Americans ... want to proceed to the identification of the various owners of the frozen assets"; to which the president of the Union Bank of Switzerland replied that for Swiss institutions to accept such identification "would ruin the entire private banking business." ${ }^{.00} \mathrm{~A}$ few days later, it was the turn of the National Bank to express its misgivings: “. . the American authorities," it wrote to the Federal Political Department,

which seem to be so scandalized by Swiss banking secrecy, might well require its progressive dismantling and demand, before the cancellation of any freezing measures, details of the names . . of the effective owners of the assets deposited in the United States under the banks' names. ... It therefore seems appropriate to examine now rather than later how best to defend the Swiss point of view in due course. ${ }^{61}$

The strategy deployed by Swiss economic and political circles in defending banking secrecy developed in two directions. First, on the "internal front," the aim was to avoid a conjunction and mutual reinforcement of the criticisms and adverse measures emanating from abroad and those being deployed on the home front. In this respect, a disturbing signal had been given in June 1942, when almost all the Socialist deputies of the National Council had signed a motion calling on

\footnotetext{
${ }^{60}$ Memorandum from Willi Reichenau of the Federal Political Department, 7 June 1943 , FAB E 2001 (E)/2/563.

${ }^{61}$ Letter from the Swiss National Bank to the Federal Political Department, 16 June 1943, FAB E 2001 (E)/2/563.
} 
"the Federal Council . . . to table shortly a proposal to the Chambers for the lifting of banking secrecy ..."62 Although this motion had been rejected during the debate in September 1943, it had nevertheless won the votes of a considerable number of non-Socialist deputies. Another disturbing sign was the significant electoral success of the Socialist Party in the federal elections of October 1943.

In this context, in December 1943, the right-wing majority of Parliament for the first time elected a representative of the Socialist Party to join the Swiss government, at the same time appointing him head of the Federal Department of Finance. True, this election was the consequence of considerations other than those described here. The fact remains, however, that, in the context of the issue of banking secrecy, this election was one of extreme efficacy. In Switzerland, the government is formed by seven ministers who are elected by Parliament and represent the major parties. However, the government functions as a collegial institution: that is, once a decision has been made, each minister has to assume it, even if he does not agree with it and his party has adopted a contrary resolution. Therefore, the newly appointed Socialist, placed at the head of the Ministry of Finance, was in the position of having to defend the Swiss financial center and Swiss banking secrecy against the criticisms and demands of the Allies because this was the orientation of the Federal Council. He even carried out this assignment with diligence. In June 1945, at one of the many hearings granted to the Swiss Bankers' Association, he actually declared that "on several occasions he had already made a point of drawing the Federal Council's attention" to the fact that the U.S. government's policy regarding Swiss banks "is strongly inspired by Wall Street, that is to say by competitive motives that Switzerland cannot afford to ignore. The Federal Council is aware of the danger and it is its duty not to abandon the banks but rather to support them." ${ }^{63}$ The ambivalent situation in which the Socialist Party found itself thus contributed to its neutralization. Henceforward, any step it might take in the direction of questioning banking secrecy would contradict the public position of its representative in the government. This explains why, paradoxically, the SocialDemocratic Left remained very discreet on this question at the end of World War II.

Once free from concern about the threat from within, Swiss ruling circles turned their attention to the external danger. To do this, they

${ }^{62}$ Résumé des délibérations de l'Assemblée fédérale, Bern, no. 4, 1943, 13.

${ }^{63}$ Quoted in Sébastien Guex/Marc Perrenoud, "Banquiers suisses et autorités fédérales face aux menaces américaines en 1945," Traverse. Revue d'Histoire, no. 3, 1995, 136. 
embarked on a policy that astutely combined three main components. In the first place, they adopted a number of delaying tactics, constantly demanding thorough legal valuations and systematically raising new technical problems. For example, in an agreement signed in March 1945 with the Allied powers, which dealt with the question of the census of the German assets in Switzerland and their expropriation, the Swiss authorities committed themselves to se concerter with the governments of several countries before taking a certain number of measures. ${ }^{64}$ In French, the verb se concerter implies that the foreign government must agree with the measure. The English translation of the agreement, however, used the expression to consult with, which is more ambiguous. There were endless discussions on whether the Swiss government's commitment was to inform the other country or whether it needed to obtain its permission.

Another example can be found in the same agreement, where the Swiss authorities also committed themselves to carry out an accurate investigation on the amount of foreign assets either in Switzerland or administered by Swiss societies. Later on, however, all kinds of technical and legal excuses were given in order to delay the accomplishment of these investigations. ${ }^{65}$ These tactics allowed the Swiss ruling circles to conduct most of their discussions with the Allies in a climate increasingly colored by the Cold War. For instance, the most important negotiations between Switzerland and the Western Allied powers started on March 18, 1946, two weeks after the resounding speech of Churchill at Fulton, denouncing the "Iron Curtain" that had fallen in the East. Therefore, it is not a coincidence that during the same discussions in Washington one of the Swiss negotiators pointed out, in an internal meeting of the Swiss delegation, that "with time, the situation can only improve for us," and another negotiator stated that "the times to come won't be unfavorable for us." ${ }^{\circ 6}$

Second, the Swiss authorities had recourse to a financial weapon. In March 1945, they granted France, at very favorable conditions for the debtor, a credit of 250 million Swiss francs (the equivalent of about 2 percent of the Swiss gross domestic product at the time). A year later, acting in parallel to the negotiations with the Western Allies in Wash-

${ }^{64}$ Quoted in P. Marguerat/L.-E. Roulet, eds., Documents diplomatiques suisses, v. 15 (Bern, 1992), 986.

${ }^{65}$ Cf. M. Durrer, Die schweizerisch-amerikanischen, 244-246; Janick Schaufelbühl, "Das Bankgeheimnis im Konflikt zwischen der Schweiz und Frankreich. Die Deblockierung der französischen Guthaben in der Schweiz, 1945-1948," Traverse. Revue d'Histoire, no. 2, 1999, 216-218.

${ }^{66}$ Quoted in L. von Castelmur, Schweizerisch-alliierte, 72. 
ington, they raised the credit to 300 million francs. Almost at the same time, on March 12, 1946, a week before the beginning of the negotiations in Washington, Great Britain was granted a loan of 260 million francs, also at very favorable conditions for the debtor. The primary objective of these important loans was to persuade the French and the English to be more accommodating and thus to weaken the coalition of the Western Allies. When explaining, in December 1945, the wish of the Federal Council to grant Great Britain a credit, the Swiss ambassador in London wrote that it was a question of "ensuring the indulgence of the English government . . . in view of the negotiations with the Allies." 67 As for the loan granted to France, a high-ranking Swiss official justified it in April 1946, shortly after the beginning of the discussions in Washington, as necessary to avoid "upsetting the French . . . in view of our extremely difficult negotiations in Washington. ... We need France politically." ${ }^{88}$ The loans fulfilled their objective. As the historian Linus von Castlemur has shown, they ensured the adoption by the British and French of a more favorable attitude toward the Swiss than that held by the Americans during the entire period of negotiations. ${ }^{69}$

Finally, Swiss ruling circles successfully mobilized Switzerland's "humanitarian capital," with the result that the Swiss government was thanked on several occasions for its humanitarian policies, notably by the president of the United States and the British prime minister, which helped in some measure to restore the country's international reputation. ${ }^{70}$ Toward the end of the war, the Swiss authorities slowly attenuated the extremely harsh nature of the policies that they had, up to that point, adopted toward refugees and, more generally, toward victims of the conflict. Several tens of thousands of refugees or former internees in concentration camps could now enter Switzerland, thousands of children coming from France were welcomed for short stays, and an effort was made to assist the repatriation of prisoners of war. The motives for these initiatives are clearly described in the letter written by the Swiss foreign minister, Max Petitpierre, on April 9, 1945, to his colleagues in the Federal Council: "Our country does not only have a humanitarian act to fulfill but also a political problem to solve. If we

${ }^{67}$ Quoted in A. Fleury, ed., Documents diplomatiques suisses, v. 16 (Zürich, 1997), 151.

${ }^{6 s}$ Quoted in J. Schaufelbühl, "Das Bankgeheimnis," 213-214.

${ }^{69} \mathrm{Cf}$. L. von Castelmur, Schweizerisch-alliierte, 49-89, 123-157.

${ }^{70}$ Cf. Walter Spahni, Der Ausbruch der Schweiz aus der Isolation nach dem Zueiten Weltkrieg (Frauenfeld, 1977), 131-133; Jean-Claude Favez, "Le Don suisse et la politique étrangère. Quelques réflexions," in B. Roth-Lochner, M. Neuenschwander, and F. Walter, eds., Des archives à la mémoire (Genève, 1995), 327-339; Hans Ulrich Jost, Le salaire des neutres. Suisse 1938-1948 (Paris, 1999), 252-263. 
contribute to save an appreciable number of miserable people, we will have a crucial argument to justify our neutrality which, as you know, is attacked by most of the Allied countries, especially by the United States and France." 1

In the autumn of 1944, Swiss authorities founded an institution, the Don suisse pour les victimes de la guerre (Swiss Donation for Victims of War), endowed with about 200 million francs that were derived partly from a collection taken up in the Swiss population. The Don suisse soon carried out rescue operations-distribution of food, clothes, and material-in several foreign countries. Again, the objectives of this institution seem clear. In fact, the deputy, Adolfo Janner, one of the persons very much in favor of the Don suisse, declared: "It will not be the Washington Agreement or our negotiations that will attract the sympathy and gratitude of the people and nations ...., but it will be solely the humble and generous humanitarian act of our people that ... will guarantee our country its place of honor and prestige in the new entente of nations." ${ }^{~} 72$ More soberly, in a letter addressed to the Federal Council, the management of the Don suisse wrote that its activities represented for Switzerland "the best way to leave the isolation in which it finds itself because of the war." 73

This policy bore fruit for the Swiss authorities, who, on the basis of the Washington Agreement signed on May 25, 1946--which was completed by the signing, on November 22, 1946, of the "Certification Agreement"-succeeded in prevailing on the Allies to suppress the blacklists and to unfreeze assets blocked in the United States without being required to undertake any appreciable weakening of banking secrecy.

Regarding that issue, however, the Swiss negotiators admittedly had to give way on one point: their demand that German assets in Switzerland, or administered by Swiss companies, be recorded and then expropriated through an anonymous procedure. In this case, the Swiss had to commit themselves to lift banking secrecy in favor of the Allies and accept that the names of the holders of these assets would, as a rule, be communicated to the Allies.

However, in Swiss political and economic circles, this was not considered to be the most crucial aspect. In their view, the essential chal-

\footnotetext{
${ }^{71}$ Quoted in P. Marguerat and L.-E. Roulet, eds., Documents, v. 15, 1053.

${ }^{72}$ Quoted in Antonia Schmidlin, "La nazione piu generosa . ..." Schweizerische Nachkriegshilfe in Italien am Fallbeispiel Centro Sociale Rimini (Basel, Lizentiatsarbeit, 1991), 38.

${ }^{73}$ Quoted in Jörg Kistler, Das politische Konzept der schweizerischen Nachkriegshilfe in den Jahren 1943-1948 (Bern, dissertation, 1980), 85.
} 
lenge was to preserve the anonymity, vis-à-vis the Allies, of the remaining foreign clientele of Swiss banking establishments, particularlyonce again-of their French depositors. ${ }^{74}$ One can better measure the importance of this stake by the fact that, of the private assets of some 5 billion Swiss francs administered under the Swiss flag and blocked in the United States, the sum of roughly 2 billion Swiss francs (about the equivalent of 150 billion French francs today) belonged to French depositors alone.$^{75} \mathrm{Had}$ the procedure of unfreezing these assets first permitted the Allies to discover the names of the actual holders of these assets, the names would ultimately have reached the French fiscal authorities. Admittedly, the owners concerned would have been able to lift the block on their frozen assets. However, by dint of French laws, they would then have been forced to repatriate their capital to France, where they would have been exposed to heavy taxation or even to prosecution for fiscal fraud. Worse still, they would have found themselves under the spotlight of the French fiscal authorities for the future.

However, the Swiss ruling circles succeeded in warding off the Allied powers' demands. First, the procedure for identifying the German assets in Switzerland, as well as the frozen Swiss assets in the United States was not carried out either by Allied civil servants or under their direct supervision. It was entrusted to a semi-state-run Swiss institution, the Office suisse de compensation (Swiss Compensation Office).$^{76}$ The Swiss preference for the Swiss Compensation Office can be explained by two factors: In terms of external politics, it seemed wise to avoid assigning to an entirely state-run institution the responsibility for such a delicate operation. As for internal politics, the decision to entrust an organization that was only partially state administered limited the danger that tax information would be leaked to other administrative departments. For good measure, the Swiss Compensation Office delegated a substantial part of its powers to the Swiss banks themselves

\footnotetext{
${ }^{74}$ Although this was the main stake at issue, there were, in fact, others. For example, the possibility of unfreezing assets administered by Swiss establishments in the United States without having to deliver the names of their real owners to the Allies-with the exception of German owners-allowed these assets to avoid American taxation. Cf. letter from Joseph Straessle, financial councilor of the Swiss Legation in Washington to the Foreign Affairs Division of the Federal Political Department, 12 Dec. 1944, FAB E 7160-02/1968/27/9.

${ }^{75} \mathrm{Cf}$. the final report of the Swiss Compensation Office on the certification of Swiss assets in the United States, April 1949, FAB E 7160-01/1968/223/324; see also the report entitled "Accusations in the Matter of the Certification of 'Swiss Assets' Frozen in the USA," signed by Paul Carry, professor of law at the University of Geneva and member of the Committee of the Swiss National Bank, 8 Feb. 1952, FAB E 2800/1967/61/91.

${ }^{76}$ On the Swiss Compensation Office, of. Benno Bissing, Die schweizerische Verrechnungsstelle (Zürich, 1942).
} 
in order to maintain international trust in the Swiss banks' ability to regulate and supervise themselves. In this context, the Allied authorities were able to exercise only indirect, relatively remote surveillance, which considerably restricted their ability to obtain information on Swiss banks and their clientele.

Second, apart from assets belonging to German citizens, the Swiss authorities were not obliged to transmit the names of the actual owners of other assets controlled by Swiss banking establishments to the Allies. Thus, most of the foreign clientele of Swiss banking establishments, particularly French investors, were able to preserve their anonymity. ${ }^{i \pi}$

Secrecy laws were therefore maintained in the face of the World War II victors, most notably the United States, which was the leading world power. The victory succeeded in conferring on Swiss banking secrecy the reputation of inviolability that still subsists today. In this way, it has contributed to cementing a lasting sense of trust between foreign depositors and the Swiss financial center.

Today banking secrecy remains a highly controversial practice, both in Switzerland and internationally. First, banking secrecy is criticized because it provides shelter to numerous dubious or illegal international deals and, most recently, because of the publicity over Jewish accounts during and after World War II. Among those who have profited from the practice during the last ten years are the dictators General Sese Seko Mobutu from Zaire and General Sani Abacha from Nigeria, who deposited a large part of the fortune they looted from their respective countries in Swiss bank accounts. ${ }^{78}$ Second, the European Union challenges the Swiss practice because it is now engaged, very timidly it is true, in unifying its tax system and is working to eliminate some existing tax loopholes. Of course the Union wants to avoid losing large amounts of its citizens' capital to banking havens in Switzerland. ${ }^{\text {iq }}$

In the criticism of banking secrecy, the issue of its origins plays a certain role. In fact, since the late 1960s, Swiss banks disseminated the idea that the Banking Secrecy Law was introduced in order to protect the victims of Nazi persecution. This version was even incorporated into a report by the Federal Council, thereby lending it official respect-

TOn this point, cf. esp. the document entitled "Fraude de certification. Fribourg. Rapport de clôture. Partie générale, du Juge d'instruction fédéral pour la Suisse romande," 19 April 1951, 1-28, FAB E $7160-01 / 1968 / 223 / 324$. 2000.

"s. Nete Zïrcher Zeitung, 28 March 2000; Finanzplatz Schweiz Informationen, Feb.

${ }^{7}$ Cf. Netue Zürcher Zeitung, 7 April 2000. 
ability. ${ }^{80}$ These propaganda efforts helped to confer additional legitimacy to banking secrecy, as manifested in the fact that almost all studies on the issue during the last decades reproduced the Council's version without hesitation. I hope this article has helped to clear up the confusion.

${ }^{80} \mathrm{Cf}$. Message du Conseil fédéral à l'Assemblée fédérale concernant la révision de la loi sur les banques, 13 March 1970, Feuille fédérale 1970, v. I (Bem), 1175. 